Jurnal Pembangunan Pendidikan: Fondasi dan Aplikasi

Volume 4, No 2, Desember 2016 (115-129)

Tersedia Online: http://journal.uny.ac.id/index.php/jppfa

\title{
KEMITRAAN PENDIDDIKAN DI ERA OTONOMI DAERAH
}

\author{
${ }^{1)}$ Fatchurrohman, ${ }^{2)}$ Suyata, ${ }^{3)}$ Sodiq Azis Kuntoro \\ ${ }^{1)}$ IAIN Salatiga, ${ }^{2,3)}$ Universitas Negeri Yogyakarta \\ ${ }^{1)}$ artur.neno@yahoo.co.id,
}

\begin{abstract}
Abstrak
Penelitian ini bertujuan untuk memahami orientasi pemikiran, implementasi dan dampak kemitraan pendidikan. Jenis penelitian ini adalah studi kasus di SMA Negeri 1, SMK Negeri 2, MAN dan lembaga sosial di kota Salatiga dengan pendekatan interpretif. Data penelitian digali melalui wawancara, observasi, dan dokumentasi. Analisis data dilakukan melalui analisis holistic, embedded, analysis of theme, within case, dan cross case analysis. Hasil penelitian menunjukkan bahwa sekolah menghadapi banyak keterbatasan, sementara lembaga sosial memiliki banyak sumber daya untuk mengatasi keterbatasan tersebut. Sekolah memiliki variasi orientasi pemikiran dan implementasi kemitraan pendidikan, yaitu akademik-profesional, akademik-vokasional, dan akademik-spiritual. Implementasi kemitraan pendidikan didukung oleh modal sosial. Penghambat kemitraan pendidikan berasal dari orang tua, sekolah, dan lembaga sosial. Pada era Otonomi Daerah partisipasi partai politik mendominasi dalam pengambilan dan pelaksanaan kebijakan pendidikan. Kemitraan pendidikan memiliki dampak signifikan terhadap mutu lulusan, budaya sekolah, dan orang tua.
\end{abstract}

Kata kunci: kemitraan, sekolah, orang tua, lembaga sosial kemasyarakatan

\section{EDUCATIONAL PARTNERSHIP IN THE ERA OF REGIONAL AUTONOMY}

\author{
${ }^{1)}$ Fatchurrohman, ${ }^{2)}$ Suyata, ${ }^{3)}$ Sodiq Azis Kuntoro \\ ${ }^{1)}$ IAIN Salatiga, ${ }^{2,3)}$ Universitas Negeri Yogyakarta \\ ${ }^{1)}$ artur.neno@yahoo.co.id,
}

\begin{abstract}
This research is aimed at understanding the mind orientation, implementation, and impact of educational partnership in the era of regional autonomy. The research was a case study in Senior High School, Vocational High School, Madrasah Aliyah Negeri, and social institution in Salatiga municipality employing interpretive approach. Data were obtained through interview, observation, and documentation. Data analysis was conducted through holistic analysis, embedded analysis, analysis of theme, analysis within case, and cross case analysis. The result of the research shows that school encounters many limitedness, while social institution has many resources to overcome the limitedness. School has variation of mind orientation and implementation of educational partnership, namely academic-professional, academic-vocational, and academic-spiritual minded. The implementation of educational partnership is supported by social capital. The obstructive factors of educational partnership can be derived from parents, school, and social institutions. In the era of regional autonomy, the participation of political parties dominates the decision and implementation of educational policy. Educational partnership has a significant impact on the quality of the graduates, school culture, and the parents.
\end{abstract}

Keywords: partnership, school, parents, social institution 


\section{PENDAHULUAN}

Salah satu masalah yang dihadapi bangsa Indonesia adalah rendahnya mutu pendidikan, khususnya jenjang pendidikan dasar dan menengah. Berbagai usaha telah dilakukan, namun belum berhasil meningkatkan mutu pendidikan nasional. Berbagai analisis (Depdiknas, 2002, p. 1), menemukan tiga faktor penyebab mutu pendidikan di Indonesia tidak merata, yaitu kebijakan pendidikan nasional yang menggunakan pendekatan $e d u$ cation production function, pendidikan nasional yang birokratik sentralistik, dan minimnya keterlibatan stakeholder di sekolah.

Salah satu upaya yang dapat dilakukan untuk meningkatkan mutu pendidikan adalah penguatan kemitraan antara sekolah, orang tua, dan institusi kemasyarakatan terkait. Menurut Buchori (2001, p. 72), "....orang tua dan masyarakat merupakan stakeholder yang selama ini diabaikan dalam pengelolaan pendidikan...". Tilaar (2004, p. 58) mengungkapkan bahwa salah satu kenyataan pendidikan masa orde baru adalah terpisahnya pendidikan dari masyarakat, akibatnya pendidikan terpisah dari kebutuhan masyarakat, dari dunia industri, dan dunia kerja. Gerakan desentralisasi pendidikan dalam UU No 22 Tahun 1999 berarti mengikutsertakan masyarakat dalam menentukan akuntabilitas pendidikan. Menurut Scott (dalam Jalal dan Supriyadi, 2001, pp. 11-160), pe-libatan guru, orang tua, dan masyarakat dalam pendidikan mampu meningkatkan rasa kepemilikan mereka terhadap sekolah, penggunaan sumber daya pendidikan lebih baik, kontrol kepala sekolah lebih besar, dan beban sekolah menjadi lebih ringan sehingga hasilnya lebih baik..

Penjalinan hubungan antara orang tua dengan sekolah pada Sekolah Lanjutan Tingkat Atas (SLTA) di kota Salatiga hingga kini belum sesuai dengan cita idal. Sebagian besar orang tua masih memiliki pemahaman yang keliru ketika memasukkan anak mereka ke sekolah. Mereka cenderung melepaskan diri dari tanggung jawab dan menyerahkan sepenuhnya tanggung jawab pendidikan anak kepada sekolah. Dalam menyelesaikan masalah anak, para pengelola pendidikan di SLTA kota Salatiga, lebih mengoptimalkan fungsi tenaga konseling di sekolah. Orang tua juga masih sulit dilibatkan dalam urusan pendidikan di sekolah.
Beberapa penelitian menunjukkan bahwa kemitraan pendidikan mampu mendorong partisipasi orang tua dan meningkatkan performa peserta didik, misalnya penelitian Crites (2008) yang berjudul Parent and community involvement: a case study dari Liberty University; penelitian Lemmer yang berjudul Parent involvement in teacher education in South Africa tahun 2007 dari University of South Africa dalam International Journal about Parents in Education; penelitian Lemmer and Wyk (2004) yang berjudul Home-School communication in South Africa Primary school, dari University of South Africa dalam South African Journal of Education; penelitian Sanders (2000), yang berjudul Creating successful school-based partnership programs with families of special needs students yang dipublikasikan di The SchoolCommunity Journal, volume 10 edisi 2, pp. 37-56; penelitian Sheldon \& Voorhis (2004) Partnership programs in U.S. schools: Their development and relationship to family involvement outcomes yang dipublikasikan di School Effectiveness and School Improvement, volume 15 edisi 2, pp. 125-148; penelitian yang dilakukan oleh Goos, Lowrie, dan Jolly (2007) yang berjudul Home, school, and community partnership in numeracy education: An Australian perspective.

Keadaan tersebut mendorong peneliti untuk mengkaji lebih dalam tentang kemitraan pendidikan di kota Salatiga pada era otonomi daerah.

\section{METODE}

Penelitian ini termasuk dalam jenis penelitian kualitatif case study kolektif dengan pendekatan interpretif, yang dilakukan dengan memberikan interpretasi atas fakta melalui uraian yang mendalam dan disesuaikan maksud pelaku kegiatan.

Penelitian ini berlokasi di SMA Negeri 1, SMK Negeri 2, dan MAN Kota Salatiga Jawa Tengah. Penelitian dilaksanakan pada bulan November 2012- Mei 2013, Juni November 2015.

Subjek dalam penelitian ini adalah kepala sekolah, wakil kepala sekolah bidang kerja sama, bidang kesiswaan, dan bidang kurikulum, komite sekolah, petugas bimbingan dan konseling, ketua lembaga/organisasi sosial kemasyarakatan, kasi kurikulum disdik- 
pora kota Salatiga, kabid dikmen disdikpora Kota Salatiga, dan orang tua peserta didik. Objek kajian yang ditekuni dalam penelitian ini adalah kemitraan antara sekolah, orang tua, dan lembaga sosial kemasyarakatan pada era otonomi daerah.

Teknik pengumpulan data dilakukan melalui wawancara, observasi, dan studi dokumentasi. Instrumen yang digunakan dalam penelitian ini meliputi pedoman wawancara, pedoman observasi, dan pedoman studi dokumentasi. Pemeriksaan keabsahan data penelitian dilakukan melalui triangulasi sumber dan metode, member checks, uraian rinci, dan konfirmasi. Data yang terkumpul dianalisis dengan mengikuti tahapan yang dikembangkan oleh Yin dan Stake (dalam Creswell, 2007, p. 75), yaitu melalui tahap holistic analysis, embedded analysis, analysis of theme, within case analysis, dan cross case analysis.

\section{HASIL DAN PEMBAHASAN}

\section{Orientasi Pemikiran Kemitraan Pendidikan}

Kemitraan pendidikan yang dikembangkan di kota Salatiga didasarkan pada orientasi pemikiran bahwa pendidikan yang bermutu merupakan tanggung jawab bersama antara sekolah, orang tua dan masyarakat dalam rangka memenuhi kebutuhan masyarakat. Sekolah adalah bagian dari institusi sosial yang berusaha memberikan pengaruh positif kepada anak namun memiliki banyak keterbatasan. Sementara itu, masyarakat memiliki banyak sumber belajar yang dapat manfaatkan melalui sekolah untuk mengatasi keterbatasan tersebut melalui outdoor learning.

Menurut Abdullah Idi (2013, p. 169), masing-masing komponen pendidikan harus saling berhubungan satu sama lainnya secara efisien dan produktif. Dalam masyarakat modern, sekolah lebih dominan melaksanakan fungsi utama karena terbatasnya interaksi anak dengan orang tua, sementara itu dalam masyarakat pedesaan, keluarga banyak menjalankan fungsi pendidikan karena terbatasnya akses pendidikan formal.

Menurut Coleman (dalam Grant, 2010, p. 39; Marsh, 2010, p. 250), guru dapat menggunakan berbagai sumber belajar di masyarakat dengan memanfaatkan jaringan sosial siswa dan keluarga, seperti keluarga besar, tetangga, anggota masyarakat, maupun kelompok masyarakat. Sumber belajar di masyarakat yang telah dimanfaatkan sekolah adalah pasar, tokoh masyarakat, pakar, taman kota, institusi pemerintah, institusi sosial kemasyarakatan, institusi keagamaan, dan museum. Menurut Drago \& Severson (Idi, 2013, p. 171), agar guru mampu mengembangkan prestasi anak didik secara optimal, sekolah perlu memiliki kapasitas dalam school organizational capacity, instructional capacity, developmental capacity.

Pendidikan diselenggarakan dalam rangka memenuhi kebutuhan masyarakat. Menurut Durkheimian (dalam Maliki, 2010, p. 94), pendidikan tidak bisa dipisahkan dari masyarakatnya. Masyarakat dan pendidikan saling berinteraksi dan saling memberi pengaruh, pendidikan selalu berkait erat dengan institusi sosial lainnya. Dalam pandangan kaum kapitalis (Maliki, 2010, p. 166), sekolah harus mampu meyakinkan kepada masyarakat bahwa sekolah menyediakan banyak pilihan tenaga kerja yang dibutuhkan masyarakat industri. Menurut Durkheimian (dalam Maliki, 2010, p. 89), masyarakat dan institusi yang ada di dalamnya seperti pendidikan, kesehatan, agama, dan lainnya merupakan komponen-komponen yang saling bergantung. Sekolah adalah bagian dari komponen sosial harus mengaitkan diri dengan komponen lain agar mampu berkontribusi dalam menciptakan harmoni sosial.

\section{Implementasi Kemitraan pendidikan}

\section{Komunikasi}

Sekolah mengadakan pertemuan dengan orang tua pada awal tahun ajaran baru, ketika penerimaan rapor, dan pelepasan lulusan. Orang tua siswa tingkat akhir diundang ke sekolah untuk sosialisasi Ujian Nasional. Pada pertemuan awal tahun ajaran, komite sekolah berperan sebagi mediator antara sekolah dan orang tua. Orang tua juga diundang ke sekolah secara perorangan, jika ada masalah terkait dengan anak mereka. Khusus orang tua siswa kelas unggulan mengadakan pertemuan setiap tiga bulan sekali. Hasil pertemuan ditindaklanjuti sesuai dengan kesepakatan, biasanya diserahkan kepada sekolah, dan jika diperlukan bisa melibatkan orang tua. Program kegiatan sekolah dan berbagai kebijakan 
lainnya disampaikan pada waktu pertemuan dengan orang tua di awal tahun ajaran baru dan pada waktu penerimaan rapor. Selain itu, informasi mengenai kegiatan sekolah yang insidentil disampaikan melalui surat, telephone, dan web sekolah.

Menurut Olsen \& Fuller (2012, p. 121), banyak media yang dapat digunakan untuk mengkomunikasikan hasil kerja siswa, kegiatan siswa, atau keadaan siswa di sekolah kepada orang tua, misalnya folders, journals, card report, narrative report ataupun newsletter. Media komunikasi yang digunakan di kota Salatiga adalah telephone, majalah, dan buku rapor. Berbagai media lain belum dimanfaatkan sekolah karena beban kerja guru yang berat dan cara pandang guru yang pesimis terhadap para orang tua siswa.

Beban guru adalah memikirkan bagaimana mengajar di kelas yang baik, mendongkrak nilai siswa dan menyelesaikan persoalan siswa sendiri atau dengan bantuan guru BK di sekolah. Para guru memberikan laporan performa anak didik setiap semester sekali, karena dipandang simpel dan tidak merepotkan kerja guru. Di luar jam kerja para guru masih harus melakukan aktivitas keluarga dan sosial.

Guru memandang bahwa seandainya mengembangkan komunikasi berkala dengan orang tua, harian, mingguan atau dua mingguan tidak akan berdampak bagi performa anak. Para guru menganggap bahwa orang tua tidak memiliki kesempatan untuk mencermati media komunikasi harian atau mingguan. Orang tua harus bekerja penuh waktu untuk memenuhi kebutuhan hidup, karena profesi orang tua siswa SMA Negeri $153.6 \%$ berprofesi sebagai pekerja swasta, orang tua siswa SMK Negeri 2 sebanyak 52.08\% sebagai petani, sedangkan orang tua siswa MAN sebanyak $41.76 \%$ berprofesi sebagai petani. Profesi tersebut membuat para orang tua lebih memikirkan pekerjaannya dari pada pendidikan anaknya.

Sekolah memberikan jaminan keamanan anak dengan membuat pagar keliling sekolah, anak pulang harus dijemput orang tua, selalu ada pemberitahuan jika anaknya ada kegiatan menginap di sekolah atau pulang terlambat, dipasang CCTV, gerbang sekolah dijaga petugas dan ditutup jam 07.00 WIB. Menurut Decker \& Virgin, (2003, p. 214), sekolah yang aman adalah sekolah yang secara fisik, tata letak dan prosedur-prosedur dirancang untuk meminimalisir gangguan pada peserta didik. Sekolah yang aman adalah sekolah yang membuat warga sekolah nyaman secara fisik dan emosional.

Komunikasi sekolah dan orang tua ini sangat diperlukan dalam rangka membangun kepercayaan (trust) antar satu dan lainnya. Menurut Hauberer (2011,p.42), hubungan saling percaya antara individu akan melahirkan harapan di satu pihak dan kewajiban di pihak lainnya.

Antara sekolah dan orang orang juga terdapat relasi kewenangan, di mana sekolah mendapat kewenangan dari orang tua untuk melakukan hal-hal yang diperlukan bagi pendidikan anaknya. Kewenangan ini diberikan orang tua kepada sekolah karena orang tua adalah memiliki banyak keterbatasan (ekonomi dan pendidikan), sehingga untuk melaksanakan tugas pendidikan anaknya, para orang tua memerlukan resources lain di luar dirinya.

\section{Pengasuhan}

SMA Negeri 1 Salatiga tidak pernah mengajari secara khusus kepada orang tua tentang pengasuhan anak di rumah. Orang tua dianggap sudah mampu mengasuh anak mereka karena mereka berpendidikan tinggi, berpengalaman dan cukup mampu. Di SMK Negeri 2 dan MAN Salatiga, pengarahan tentang pengasuhan disampaikan pada forum pertemuan orang tua dengan sekolah secara masal.

Orang tua diminta untuk mendorong agar anaknya mengikuti kegiatan yang diselenggarakan di sekolah, seperti remidi, tambahan pelajaran, terutama bagi keluarga yang kurang mampu. Sekolah menyadari waktu anak lebih banyak di rumah dari pada di sekolah.

Menurut Jensen (2010, p. 4), orang tua dan guru perlu menciptakan lingkungan yang kondusif bagi anak. Lingkungan belajar yang diciptakan harus nyaman secara fisik, emosional, dan sosial bagi anak. Menurut Dermott (2008, pp. 42-93), parenting merupakan upaya menyediakan suasana yang kondusif bagi pengembangan fisik dan emosi anak, membangun relasi emosi berdasarkan rasa cinta kasih, membimbing anak untuk memahami dunia dan budaya dan merancang lingkungan yang baik secara bersama-sama. 
Keberhasilan dan kegagalan parenting tergantung pada banyak hal menyangkut kesulitan-kesulitan yang dihadapi oleh anak dan tingkatan masalah yang ada di lingkungan sosial anak dan orang tua, yang tidak menyehatkan dan tidak memotivasi. Dengan demikian, penciptaan lingkungan belajar yang kondusif bagi anak di rumah menuntut adanya pengaturan lingkungan fisik dan penciptaan suasana yang mampu memberikan kenyamanan anak dalam belajar baik secara fisik, emosinal dan juga sosial.

Dalam praktiknya, hal-hal yang perlu diperhatikan orang tua dan guru dalam mengatur lingkungan untuk belajar adalah : (a) suhu ruangan yang baik berkisar antara 20 $-25^{\circ} \mathrm{C}$; (b) tanaman, bunga, atau kembang; (c) akustik, dan mutu suara; d) poster, warna tembok; (e) bagus juga dipasang icon-icon affirmative di ruang belajar; (f) penerangan (alami atau listrik); g) binatang peliharaan, dan aquarium; (h) kursi tempat duduk; (i) tingkat kelembaban ruangan; $j$ ) pemandangan keluar; (k) penciuman, aroma positif di ruangan; (1) iringan musik.

Selain penataan lingkungan fisik, suasana kondusif juga terwujud melalui penciptaan lingkungan sosial yang baik dalam keluarga. Menurut Tate (2013, p. 229), beberapa suasana yang diperlukan untuk mendukung suasana yang kondusif bagi pembelajaran anak di rumah antara lain: (a) mengembangkan hubungan positif dengan anak; (b) memberikan pelukan dan mencintai anak; (c) menciptakan lingkungan yang tenang; d) memberikan contoh yang baik; (e) membangun komunikasi positif dengan anak; (f) menemani anak belajar; (g) memberi kesempatan anak untuk mengembangkan kreativitas; (h) mengajarkan aturan, ritual dan tanggung jawab; (i) menekankan hal-hal yang positif; dan (j) membuang hal-hal yang negatif.

Moon\&Trickett (dalam Marsh, 2010, p. 83), menambahkan bahwa suasana psikologis di ruangan yang mempengaruhi belajar anak antara lain hubungan interpersonal di antara anggota keluarga, tingkat perkembangan individu, dan cara kontrol dari orang tua.

Dalam hal penciptaan lingkungan sosial, beberapa hal yang sudah dapat diwujudkan pada keluarga siswa SMA, MAN dan SMK Negeri 2 Salatiga, antara lain: hubungan positif dengan anak, memberi kesempatan anak untuk mengembangkan kreativitas, mengajarkan aturan, ritual dan tanggung jawab, menekankan hal-hal yang positif, membuang hal-hal yang negatif.

Hasil riset Gottfried \& Flemming tahun 1998 dan Meece tahun 2002 (dalam Schunk, Pintrich \& Meece, 2012, p. 429), menunjukkan bahwa orang tua yang menyediakan lingkungan keluarga yang hangat, responsive, dan supportive mampu mendorong eksplorasi, menstimulasi keingintahuan, dan menyediakan materi bermain dan materi belajar mempercepat perkembangan intelektual anak-anak. Lingkungan keluarga yang mampu menyediakan stimuli tersebut melahirkan anak yang memiliki motivasi dan prestasi akademik lebih di sekolah. Menurut Schunk, Pintrich \& Meece (2012, p. 128), relasi anak dengan orang tua penting karena orang tua mempunyai pengaruh nomor satu terhadap perkembangan hidup anak sampai usia lima tahun, selanjutnya bergeser ke taman sebaya dan orang tua memberikan perhatian individual kepada anaknya yang tidak dapat dihasilkan oleh guru. Rekomendasi hasil penelitian ini, adalah perlunya program-program peningkatan pengetahuan orang tua tentang cara menyediakan pengalaman belajar yang kaya bagi anak-anak mereka.

Dalam mengasuh anak, orang tua juga perlu diberi pemahaman yang baik dan benar mengenai makanan dan konsumsi nutrisi dan pengaturannya. Orang tua perlu diberi penjelasan yang memadai tentang pentingnya sarapan pagi, konsumsi nutrisi yang mencerdaskan otak dan menghindari makanan-makanan yang menyebabkan kantuk atau menurunkan daya kerja otak. Selain itu orang tua juga perlu diberi pengetahuan tentang variasi pengaturan menu makanan setiap harinya, sehingga anak tidak malas makan di rumah.

Menurut Novie (2012, p.1), sarapan pagi merupakan upaya untuk memenuhi kebutuhan tubuh akan nutrisi yang sangat dibutuhkan otak saat akan bekerja. Penelitian Sendai (2010), membuktikan bahwa sarapan pagi menunjang perkembangan otak, khususnya bagian-bagian otak yang penting untuk menunjang aktivitas belajar. Penelitian Mahoney tahun 2004 (Novie, 2012, p. 2), menyimpulkan bahwa makanan yang di-konsumsi sebelum ke sekolah adalah jenis makanan yang mengandung karbohidrat berserat tinggi atau karbohidrat kompleks. Penelitian Taki menunjukkan bahwa jenis sarapan yang 
paling baik untuk sarapan anak sebelum berangkat ke sekolah adalah nasi karena diketahui bahwa anak-anak yang makan nasi setiap pagi sebelum ke sekolah memiliki hasil tes yang lebih baik. Bagian-bagian otak yang penting untuk tugas kognitif seperti prefrontal cortex, orbitofrontal cortex, dan cingulate, mengalami penebalan materi abu-abu dan materi putih.

Dalam menyediakan menu seharihari, orang tua perlu memahami tentang jenis makanan yang mampu meningkatkan daya kerja otak, agar kekuatan kerja otak anak dapat maksimal. Orang tua juga perlu memilih bahan makanan yang organik. Penelitian terbaru menunjukkan bahwa adanya hubungan antara pestisida dalam pertanian dengan melemahnya daya ingat, munculnya depresi, perubahan suasana hati atau agresivias (Paretta, 2004, p. 24).

Menurut Febry \& Marendra (2009, p. 20), ada dua belas jenis makanan yang dijuluki brain food, yang sangat baik untuk anak usia sekolah karena mampu merangsang pertumbuhan sel-sel otak, memperbaiki fungsi otak, meningkatkan daya ingat, dan konsentrasi berpikir. Keduabelas jenis makanan tersebut adalah ikan dan kerang-kerangan, telur, daging sapi, daging ayam, gandum murni, Oat/oatmeal, beras merah, kelompok berry, kacang-kacangan, buah dan sayuran berwarna, susu dan yogurt, keju.

Selain diberi informasi tentang makanan-makanan yang mampu membantu meningkatkan kinerja otak anak, orang tua juga perlu diberi informasi tentang jenis makanan yang menurunkan daya kerja otak anak. Menurut Unoviana (2014, pp. 1-2) beberapa jenis makanan yang dapat menurunkan kinerja otak anak adalah omelet putih telur, agave, tuna, popcorn microwave, biskuit dan keripik, makanan berkadar gula tinggi, alkohol, junk food, makanan yang digoreng, makanan yang sangat asin, pemanis buatan, nikotin. Pendapat lain, dikemukakan oleh Paretta (2004, pp. 71,87,89,93), pengaturan konsumsi nutrisi bagi anak agar mampu menopang aktivitas otaknya. Jenis-jenis menu makanan yang disarankan untuk dikonsumsi anak usia sekolah adalah mencakup menu untuk keningkatkan IQ, menu untuk penguat otak, makanan untuk membantu menghalau dan mengatasi stress anak.
Anak terkadang juga merasakan kantuk ketika mengikuti kegiatan pembelajaran di sekolah yangdiakibatkan oleh berbagai faktor, misalnya faktor fisik karena kecapaian, pembelajaran yang tidak menarik, suasana ruangan yang tidak kondusif, atau karena faktor makanan. Menurut Widjaya (2014, p.1), beberapa makanan yang disarankan agar tidak dikonsumsi anak ketika akan belajar agar tidak cepat mengantuk adalah pisang, teh hijau, susu, buah Ceri, sereal, kacang Almond, kedelai.

Berbagai jenis makanan tersebut tentunya tidak semuanya dapat dijumpai orang tua siswa SMA, MAN dan SMK Negeri 2 Salatiga. Untuk mengatasi hal tersebut, orang tua dapat memanfaat potensi sumber makanan yang ada disekitarnya guna memenuhi kebutuhan gizi anaknya, misalnya kelompok sayuran seperti sayuran hijau, daun singkong, daun sawi, brokoli, bayam, jagung, kangkung, brokoli, kubis, kembang kol, cabe, jamur, wortel, buncis, labu, mentimun, dsb; kelompok kacang-kacangan misalnya wijen, kedelai, kacang tanah, kacang hijau, biji bunga matahari, kacang mete, dsb; kelompok buah-buahan seperti pisang, papaya, jeruk, tomat, apel, alpukat, mangga, kelengkeng, duku, rambutan, manggis, durian; kelompok lauk pauk misalnya tahu, tempe, ikan air tawar, hati sapi, daging sapi, telur, udang, lele, gurami, nila, belut, daging ayam, bebek; kelompok sumber energi misalnya singkong, beras, bekatul, jagung, umbi-umbian, kentang, dedak; kelompok lain seperti susu sapi dan susu kedelai.

Sekolah-sekolah di Salatiga melakukan home visit untuk mengatasi masalah anak yang berat, sementara orang tua tidak dapat dihadirkan ke sekolah karena alasan tertentu. Masalah yang tergolong berat misalnya, anak berkelahi di sekolah, anak merokok di sekolah, anak membolos, skor pelanggaran anak sudah mencapai angka tinggi, anak sering melanggar tata tertib. Home visit dilakukan setelah sekolah melakukan pembinaan kepada anak namun tidak menghasilkan perubahan yang lebih baik.

Home visit yang dilakukan sekolah memiliki tujuan dan alasan tertentu, yaitu untuk memahami peserta didik dan keluarganya lebih baik, sebagai salah satu wujud empati sekolah terhadap keluarga mereka, orang tua sulit dihadirkan ke sekolah, dan untuk mengimplementasikan program pendi- 
dikan keluarga di rumah bagi anak-anak yang memerlukan bimbingan khusus.

Penelitian Meyer \& Mann (dalam Grant \& Ray, 2010, p. 229; Olsen \& Fuller 2012, p. 112), menemukan bahwa home visit mampu memperkuat kerja sama antara sekolah dan orang tua, sembilan puluh satu persen orang tua mengakui home visit dapat meningkatkan motivasi belajar anak mereka. Penelitian Kyle menemukan bahwa home visit dapat digunakan untuk memberikan tambahan pengetahuan kepada orang tua dan merencanakan pertemuan lain sesuai dengan keadaan dan kebutuhan keluarga, banyak orang tua yang menyampaikan keluhan tentang sulitnya mendampingi anaknya dalam belajar matematika, home visit dapat meningkatkan relasi positif antara sekolah dan keluarga pendatang baru. Sekolah perlu memberikan pengetahuan persekolahan terhadap keluarga dan memahami lebih mendalam tentang keluarga agar dapat memberikan layanan yang tepat bagi anak mereka di sekolah.

Dalam konteks hubungan sekolah dan orang tua, kegiatan pengasuhan (parenting) merupakan salah satu upaya untuk menyinkronkan antara penanaman nilai (value) di sekolah dan di rumah. Sekolah dan rumah harus memiliki kesamaan dalam menanamkan nilai kepada anak. Nilai yang ditanamkan di sekolah harus diperkuat di lingkungan keluarga. Menurut Brembeck (dalam Bahar, 1989, p. 127), jika terjadi pertentangan penanaman nilai antara sekolah dan keluarga maka terjadi discontinuity pada anak, dimana anak merasa bimbang atas nilai yang diterimanya.

Kegiatan pertemuan antara sekolah dan orang tua, dalam pandangan Fennema and Tillie (dalam Castiglione, Deth, \& Wolleb (Ed), 2008, p. 353), dapat memperkuat ikatan jaringan karena karakteristik ikatan yang menghubungkan, yaitu frekwensi, semakin tinggi frekuensi pertemuan antara sekolah dan orang tua maka akan semakin kuat ikatan jaringan keduanya. Dalam hal ini, pertemuan orang tua dan sekolah yang dilaksanakan tiga kali dalam setahun tergolong rendah frekuensinya, sehingga ikatan jaringan antara sekolah dan orang tua dapat dikatakan rendah. Akibatnya, relasi antara sekolah dan orang tua sebatas relasi formal, relasi kerja, relasi birokratik yang pada akhirnya orang tua kurang dapat melibatkan diri sepenuh dalam kegiatan pendidikan di sekolah.
Dalam penjalinan ikatan relasi ini, sekolah merupakan pihak pengendali. Minimnya desain pertemuan sekolah dan orang tua disebabkan oleh faktor kebijakan dan human resources di sekolah. Kebijakan sekolah masih dominan pada kebijakan sukses ujian nasional karena masyarakat masih menjadikan prestasi ujian nasional masih menjadi tolok ukur mutu sekolah, prestasi harian siswa banyak yang masih di bawah KKM, dan orang tua kurang memperhatikan kesiapan belajar anaknya menghadapi ujian nasional. Faktor human resource di sekolah masih didominasi oleh orang-orang yang menggunakan job deskripsi lama, di mana pengembangan kemitraan pendidikan tidak mendapatkan perhatian. Akibatnya kemitraan yang berkembang mengalir apa adanya. menurut Mizruzhi, kohesivitas kelompok seperti ini terjadi secara objektif, yaitu penjalinan ikatan antar individu atau kelompok terjadi dengan sendirinya, alami, tanpa rekayasa, dan tidak terprogram. Kohesi kolektif objektif seperti ini berjalan lambat.

Sementara itu, upaya sekolah untuk mengkomunikasikan hasil kerja siswa kepada orang tua merupakan bentuk relasi timbal balik relasi kewenangan antara sekolah dan orang tua. Kegiatan ini merupakan konskuensi logis dari pihak sekolah yang telah menerima trust dan kewenangan dari orang tua untuk mendidik anaknya.

\section{Pembelajaran di Rumah}

Sekolah-sekolah di Salatiga selama ini belum menyediakan informasi kepada orang tua tentang kebutuhan belajar anak yang harus dikuasai di sekolah. Informasi tentang kebutuhan belajar anak, disampaikan sekolah dalam bentuk buku pedoman akademik dan tata tertib sekolah yang dibagikan kepada orang tua pada awal tahun ajaran. Sekolah juga belum memiliki science corner bagi para orang tua untuk menambah pengetahuan dan skill mereka dalam pendampingan anak.

Menurut Scott (dalam Olsen\&Fuller, 2010, p. 106), para guru berpandangan bahwa orang tua perlu mengupgrade pengetahuan dan skill mereka tentang berbagai mata pelajaran sehingga dapat mendampingi anaknya belajar di rumah. Orang tua juga perlu adaptif dalam penguasaan skill komputer dan berbagai teknologi informasi dan komunikasi saat ini. Dengan menyediakan forum dan sudut science tersebut maka orang tua memiliki 
kesempatan untuk meningkatkan pengetahuan dan skill tersebut.

Namun, keadaan orang tua yang sebagian besar berasal dari golongan ekonomi menengah ke bawah (MAN Salatiga, orang tua bekerja di sektor swasta $41,76 \%$, petani 16,13\%; di SMK Negeri 2 Salatiga orang tua yang bekerja sebagai buruh $25,87 \%$, swasta $52,08 \%$, dan petani $8,27 \%$ ), dan berpendidikan rendah (orang tua MAN Salatiga lulusan SD $40,6 \%$, SLTP $33,8 \%$ ), kurang memungkinkan tercapainya harapan tersebut. Di SMA Negeri 1 Salatiga keadaannya berbeda, orang tua yang tingkat pendidikan dan ekonomi menengah ke atas memiliki kesadaran yang cukup baik dalam memenuhi kebutuhan belajar anak-anak mereka (orang tua yang bekerja di sektor swasta $53,6 \%$, PNS 39,8\%, TNI/ POLRI $5,1 \%$; sedangkan dilihat dari tingkat pendidikan mereka, yang berpendidikan SLTA 31,6\%, S1 7,5 \%, S2 0,6 \%). Para siswa SMA Negeri 1 Salatiga sebagian besar (sekitar 85\%) mengikuti les tambahan setelah pulang sekolah, baik di lembaga bimbingan belajar seperti Primagama, Gama Exacta atau mengundang guru les ke rumah (les private).

Satu terobosan yang dikembangkan di MAN Salatiga adalah membentuk kelompokkelompok belajar bagi peserta didik kelas XII. Kelompok belajar ini untuk mengatasi minimnya perhatian orang tua dalam pendampingan belajar anak di rumah karena minimnya pengetahuan orang tua tentang belajar ataupun karena kesibukan orang tua bekerja mencari nafkah.

Selama ini, para orang tua menghabiskan waktunya untuk bekerja pada siang hari, sementara pada malam hari mereka gunakan untuk beristirahat atau bahkan menyelesaikan pekerjaan yang terntunda pada siang hari. Mereka tidak mengetahui bagaimana cara mendampingi belajar anak dan bagaimana mengarahkan masa depan anak mereka. Mereka tidak berbuat bukan berarti mereka tidak peduli, namun karena ketidakahuannya akan seluk beluk pendidikan anaknya.

Sedangkan untuk penyediaan sudut science, untuk sekolah di wilayah Salatiga belum memungkinkan terutama dilihat keadaan orang tua. Dilihat dari sisi sekolah sebenarnya SMA Negeri 1, MAN dan SMK Negeri 2 Salatiga mampu menyediakan corner science untuk para orang tua siswa, namun seandainya corner science tersebut disediakan, maka orang tua siswa belum tentu bersedia memanfaatkannya untuk peningkatan kemam- puan akademik mereka.

Dalam hal pengendalian kegiatan siswa di rumah, SMA Negeri 1 Salatiga mengendalikan kegiatan belajar anak di rumah melalui pekerjaan rumah (home work), SMK Negeri 2 Salatiga mengendalikan kegiatan anak di rumah melalui persaratan dalam BKK, MAN Salatiga mengendalikan kegiatan anak di rumah dengan memberi pekerjaan rumah dan buku kegiatan harian yaitu mutaba'ah yaumiah.

Dalam memberikan tugas pekerjaan rumah, pihak sekolah menyerahkan kebijakan kepada para guru bidang studi dalam memberi, menentukan jenis, mengevaluasi, dan penghitungan hasil pekerjaan rumah.

Dalam pembelajaran komplementer, pembentukan performa anak akan dipengaruhi oleh pengalaman mereka yang diperoleh di sekolah dan dan di luar sekolah. Peran-peran di luar yang mempengaruhi peserta didik sepulang sekolah misalnya program-program kegiatan yang bersifat insidentil, kegiatan olah raga, seni, musik, dan interaksi dan dorongan dari keluarga di rumah akan sangat memengaruhi pengembangan diri anak (Weiss, 2010,p.120). Kegiatan anak di luar sekolah yang paralel dengan nilai-nilai yang dikembangkan di sekolah akan sangat mendukung percepatan pembentukan performa anak yang ideal.

Menurut Larson \& Verma (Weiss,2010, p. 122), waktu yang digunakan anak di luar sekolah sejak bangun tidur adalah $70 \%$, sedangkan waktu anak untuk kegiatan di sekolah hanya $30 \%$. Oleh karena itu perlu diupayakan berbagai cara untuk memaksimalkan mengelola waktu anak setelah pulang dari sekolah, memperpanjang waktu di sekolah, dan pembentukan berbagai komunitas yang edukatif.

Banyak silang pendapat di kalangan ahli didik mengenai pemberian tugas pekerjaan rumah (home work) kepada anak didik, sebagian tidak menyetujui dan sebagian yang lain menyetujuinya. Bagi yang tidak menyetujui adanya pekerjaan rumah, mereka beralasan bahwa pekerjaan rumah merupakan akar dari semua kekerasan di sekolah karena jika siswa tidak mengerjakan pekerjaan rumah maka berarti dia memilih untuk dihukum. Menurut Glasser (1990, p. 250), jika suatu sekolah 
ingin berkualitas, maka harus menghindari mewajibkan pekerjaan rumah bagi siswanya.

Glasser (1990, p. 254) melanjutkan, bahwa tugas pekerjaan rumah itu adalah kontra produktif bagi guru dan siswa, siswa merasa benci dengan tugas tersebut, sementara bagi guru menghalanginya untuk membuat perencanaan pengajaran yang menarik karena ia harus mempersiapkan tugas pekerjaan rumah bagi siswanya.

Namun, jika sekolah mengambil kebijakan meniadakan tugas pekerjaan rumah, maka guru dituntut harus membuat perencanaan dan menyelenggarakan pembelajaran yang bermutu. Sebagian guru yang memberi tugas pekerjaan rumah kepada para siswa karena ia tidak mampu menyelesaikan materi sesuai dengan target kurikulum yang telah ditentukan.

Sekolah memberikan pengarahan kepada orang tua tentang cara membantu anak belajar di rumah melalui forum pertemuan antara orang tua dan sekolah, ome visit; telephone, sms, surat. Isi pengarahan sekolah adalah orang tua diminta memperhatikan anaknya ketika di rumah.

Dari ketiga sekolah yang dijadikan objek studi, yaitu SMA Negeri 1, MAN dan SMK Negeri 2 Salatiga, orang tua SMA Negeri 1 Salatiga yang dipandang memiliki kesadaran yang tinggi dan memahami bagaimana mendampingi belajar anak di rumah, karena mereka adalah orang-orang yang berpendidikan. Kalau dilihat dari tingkat pendidikan orang tua, SMA Negeri 1 memang lebih tinggi dibandingkan dengan kedua objek sekolah lainnya di Salatiga sebagaimana digambarkan pada Tabel 1.

Tabel 1. Tingkat Pendidikan Orangtua

\begin{tabular}{cccccccc}
\hline Sekolah & $\begin{array}{c}\text { S3 } \\
(\%)\end{array}$ & $\begin{array}{c}\text { S2 } \\
(\%)\end{array}$ & $\begin{array}{c}\text { S1 } \\
(\%)\end{array}$ & $\begin{array}{c}\text { Diploma } \\
(\%)\end{array}$ & $\begin{array}{c}\text { SLTA } \\
(\%)\end{array}$ & $\begin{array}{c}\text { SLTP } \\
(\%)\end{array}$ & $\begin{array}{c}\text { SD } \\
(\%)\end{array}$ \\
\hline SMAN 1 & 0,6 & 8 & 40 & 10 & 31,6 & 6,8 & 3,0 \\
SMKN 2 & 0 & 0,1 & 8,1 & 3,3 & 44,4 & 19,2 & 24,9 \\
MAN & 0 & 0 & 3,7 & 0 & 21,9 & 33,8 & 40,6 \\
\hline
\end{tabular}

Orang tua harus senantiasa diberi pemahaman tentang pentingnya mengatur waktu bagi anaknya di rumah. Menurut Larson \& Verma (Weiss, 2010, p. 122), waktu yang digunakan anak di luar sekolah sejak bangun tidur adalah $70 \%$, sedangkan waktu yang digunakan untuk kegiatan belajar di se- kolah $30 \%$. Orang tua perlu membantu anak untuk memaksimalkan waktu belajar di luar sekolah, termasuk mengelola waktu anak setelah pulang dari sekolah dan pembentukan berbagai komunitas yang edukatif.

\section{Sukarelawan}

Sekolah-sekolah di Salatiga belum memiliki program mengidentifikasi potensi relawan yang ada di sekitarnya. Kegiatan volunteering selama ini dilaksanakan secara insidentil seperti program tahfidz, pramuka, PMR, dan lainnya. Identifikasi dilakukan terhadap orang tua, guru dan unsur lain yang terkait dalam hubungannya dengan seleksi calon anggota komite sekolah.

Di kota Salatiga banyak sekali organisasi kemasyarakatan yang dapat diajak bermitra menjadi relawan bagi sekolah. Lembaga-lembaga tersebut bergerak dalam sepuluh bidang kegiatan, yaitu kesehatan, hankam sosial (7 lembaga), sosial keagamaan (16 lembaga), seni budaya (7 lembaga), sosial kemasyarakatan (8 lembaga), bisnis ekonomi (5 lembaga), konstruksi teknik sipil (3 lembaga), pendidikan keluarga kewanitaan (2 lembaga), pembinaan generasi muda (7 lembaga), pembinaan profesi (4 lembaga) (daftar lembaga terlampir).

Jika melihat dari kegiatan relawan di sekolah yang selama ini sudah dilaksanakan, ada lima tema besar kegiatan relawan yang dilaksanakan di sekolah, yaitu tema akademik, non-akademik, kesehatan, hukum dan kewirausahaan; sementara itu bidang-bidang lain seperti kesenian, olah raga, hankam, sosial kemasyarakatan, hobbi belum dapat dikembangkan oleh relawan di sekolah karena pihak sekolah sudah terlalu banyak disibukkan dengan kegiatan 'tupoksi' persekolahan, yaitu kegiatan pembelajaran formal. Sementara pihak relawan kurang memahami bahwa sekolah juga dapat dijadikan sebagai objek realisasi program kerjanya. Realisasi program kerja institusi-institusi sosial tersebut selama ini baru terkonsentrasi pada internal member.

Kalau dicermati di sekitar sekolah, sebenarnya banyak sekali sumber daya (resource) atau modal (capital) yang dapat dimanfaatkan untuk memajukan sekolah. Hopkins (2007, p. 117) menyebutkan ada tiga capital yang harus dimiliki sekolah, yaitu intellectual capital, social capital, organi- 
zational capital agar dapat mewujudkan sekolah yang bermutu.

Dalam perspektif social capital, antara sekolah dan beberapa lembaga lain belum mengoptimalkan koneksi mutualistik. Koneksi ini yang terkadang saling tidak dipahami oleh sekolah dan lembaga-lembaga sosial kemasyarakatan, yang pada akhirnya mereka saling jalan sendiri dalam mewujudkan visinya. Sebagian dari mereka sudah mengetahui hal tersebut namun karena faktor tertentu jalinan kemitraan tersebut tidak dapat diwujudkan.

Sejalan dengan keadaan tersebut, Nelson (dalam Marsh, 2010, p. 249) menyatakan bahwa salah satu sumber belajar yang dapat dimanfaatkan dalam pembelajaran adalah masyarakat lokal karena masyarakat kaya akan materi ajar, untuk memperkuat kerjasama sekolah dan masyarakat, memupuk rasa bangga pelajar, menjadikan materi pelajaran lebih relevan dengan kebutuhan anak didik, memperkenalkan model pembelajaran yang variatif. Nelson (dalam Marsh, 2010, p. 250), menyebutkan bahwa hal-hal yang dapat dijadikan sebagai sumber belajar dalam masyarakat adalah sumber daya budaya, orang yang memiliki pekerjaan khusus dan pensiunan, kelompok masyarakat, asosiasi, dan organisasi sosial, surat kabar lokal

Jika sekolah dapat menggandeng $v o$ lunteer ke sekolah, banyak hal yang dapat dikerjakan untuk membantu sekolah. Menurut Stein's\& Thorkildsen's (dalam McNergency\& Herbert, 2001, p. 270), beberapa kegiatan yang dapat dilakukan relawan adalah membantu di kantor, membantu kegiatan sekolah, menjadi guru pembimbing siswa bagi yang membutuhkannya di luar jam pelajaran, membantu dalam penerbitan newsletter, menjadi salah satu nara sumber bagi para guru, bertindak sebagai penghubung bagi keluarga yang tidak dapat berkomunikasi dengan baik, membantu kelompok belajar siswa, mengumpulkan sumber materi ajar, menjadi penasehat para siswa, menyediakan bantuan bagi pengerjaan tugas pekerjaan rumah bagi para siswa.

Pelibatan orang tua dalam berbagai kegiatan sekolah dilaksanakan melalui perwakilan komite sekolah, yang terlibat mulai dari perencanaan, pelaksanaan dan pengawasan. Ssekolah juga memiliki data lengkap orang tua siswa yang disimpan di ruang Bimbingan Konseling.
Menurut Olsen\&Fuller (2012, p. 184), sekarang telah terjadi perubahan paradigma pengelolaan pendidikan dari agency orientation approach (pendekatan berorientasi pada lembaga, sekolah) ke family centered intervention (intervensi yang berpusat pada keluaga). Agency orientation approach berpandangan bahwa mewujudkan sekolah yang bermutu dilakukan dengan memperkuat manajemen internal sekolah, sementara paradigma family centered intervention berpandangan bahwa sekolah yang bermutu dapat diwujudkan dengan mengoptimalkan keterlibatan keluarga dalam pengelolaan pendidikan anak di sekolah.

Perubahan orientasi ini didasarkan pada realitas bahwa keluarga adalah institusi yang pertama dan utama dalam pendidikan anak. Nilai-nilai yang diwariskan dalam pendidikan keluarga sangat dominan dalam membentuk performa anak. Sementara itu, pendidikan di sekolah adalah pendidikan lanjutan yang berfungsi melengkapi kekurangan dalam pendidikan dalam keluarga.

\section{Pengambilan Keputusan}

Kepala sekolah di Salatiga sebelum mengambil keputusan meminta pertimbangan kepada guru dan karyawan dan selalu mengapresiasi dan menindaklanjuti usulan dari bawah yang bermaksud ingin memajukan sekolah. Kepala sekolah meminta kepada guru dan karyawan usulan yang rinci sampai pada tahap pelaksanaannya. Usulan guru atau karyawan tersebut kemudian dibahas di forum rapat sekolah. Kepala sekolah sangat terbuka dalam kepemimpinan, terbuka menerima saran dan kritik, suka berdiskusi di manapun.

Dalam istilah manajemen, kepemimpinan partisipatif juga dikenal dengan nama kepemimpinan terbuka, bebas atau non-directive (Nasution, 2005, p. 32). Kepala Sekolah yang menganut pendekatan ini, sedikit memegang kendali dalam proses pengambilan keputusan, memaparkan informasi mengenai suatu permasalahan dan memberikan kesempatan kepada guru dan karyawan untuk mengembangkan strategi dan memecahkannya.

Menurut Yukl, (1998, pp. 134-135), secara umum keuntungan pengambilan keputusan partisipatif adalah meningkatkan kualitas keputusan karena pengambilan keputusan melibatkan orang banyak. Pengambilan keputusan partisipatif juga dapat meningkatkan 
komitmen dan rasa tanggungjawab bersama terhadap keputusan yang telah diambil.

Untuk pengembangan sekolah, mereka belum memiliki dynamic group permanen, yang ada adalah tim kerja insidentil. Pengembangan kelembagaan diserahkan kepada unit terkait, misalnya waka kurikulum, waka sarpras, waka kesiswaan atau bakat minat. Tim kerja yang dibentuk secara insidentil misalnya pada kegiatan UN, PHBI, PPDB.

Istilah lain yang serupa untuk menyebut semacam dynamic group adalah tim kerja (team work), yaitu sekelompok individu yang bekerja dan mampu menghasilkan kinerja yang lebih tinggi dari pada kerja individual (Robins\&Judge, 2007, pp. 406-408). Dalam praktiknya, ada berberapa jenis tim kerja, yaitu: (a) tim penyelesaian masalah (problem solving team); (b) tim kerja yang mengelola diri sendiri (self-managed-work-team); (c) tim lintas fungsional (cross-functional-team); (d) tim virtual (virtual team).

Dalam suatu organisasi, human capital berperan sangat penting, terutama top leader. Antara human capital dan social capital terdapat relasi komplementer. Kepala sekolah sebagai human capital sangat penting bagi terwujudnya organisasi yang efektif, namun human capital ini tidak akan dapat menjalankan roda organisasi secara optimal manakala tidak memiliki kemampuan social capital, yaitu kemampuan menjalin hubungan dengan stakeholder yang ada. Dalam konteks organisasi persekolahan, kompetensi human capital terlihat pada kemampuan kepala sekolah dalam mengembangkan gaya kepemimpinan yang mampu mengakomodasi ide, gagasan, usulan dan kepentingan berbagai pihak yang menjadi anggota orgaisasi. Pelibatan berbagai pihak dalam kepemimpian kepala sekolah mampu meningkatkan rasa kepemilikan (sense of belonging) mereka terhadap sekolah.

Komite sekolah merupakan salah satu bentuk sosial capital yang berupa organisasi yang disengaja, yang sengaja dibentuk oleh sekolah dalam rangka mensupport eksistensi sekolah. Dalam praktiknya, komite sekolah belum mampu memfungsikan dirinya secara ideal terutama anggota eksternal karena faktor dari dalam dan luar. Faktor dari dalam adalah sekolah, yaitu tingginya volume kerja di sekolah sehingga sekolah tidak memiliki waktu yang cukup untuk melibatkan komite sekolah dalam berbagai kegiatan secara penuh. Faktor dari luar berasal dari anggota komite eksternal yang memiliki kesibukan tinggi, sehingga tidak dapat terlibat secara penuh dalam keseluruhan kegiatan sekolah.

\section{Bekerjasama dengan Masyarakat}

Sekolah-sekolah di Salatiga memiliki cara yang sama dalam menginformasikan kegiatan layanan masyarakat kepada orang tua atau peserta didik, yaitu ditempel di papan pengumuman yang terletak di depan ruang BK misalnya informasi dari berbagai lembaga kursus semacam Primagama, Gama Exacta, Ganesa dan kursus-kursus bahasa Inggris., sosialisasi per kelas dengan menggunakan jam pelajaran BK misalnya sosialisasi penerimaan mahasiswa baru, surat edaran, melalui, dan website informasi tentang sister school dan tata cara pendaftaran calon peserta.

Menurut Garbarino (dalam Berns, 2004, p. 428), sekolah dan orang tua harus mengetahui berbagai layanan yang ada dalam masyarakat. Tujuannya adalah untuk membantu orang tua dan anaknya mengatasi masalahnya dan untuk menghindari penyimpangan yang lebih lanjut. Berbagai layanan masyarakat ini berbeda antar komunitas yang satu dengan yang lainnya

Sekolah melakukan kegiatan bersama dengan institusi-institusi di kota Salatiga seperti donor darah dan kegiatan ekstrakurikuler, periksa gigi gratis, penyuluhan narkoba dan kesadaran berlalu lintas, tes bakat. Kegiatan sekolah bersama berbagai elemen masyarakat, misalnya festival budaya, pentas seni, jalan santai jeda semester, hari raya Idul Fitri, hari Raya Qurban, PHBI, wisuda, bantuan tanggap bencana alam, bazaar, dan bhakti sosial pada saat kemah bhakti. Sementara itu, kegiatan sekolah bersama alumni dalam bentuk reuni, bantuan beasiswa, bantuan peralatan pembelajaran di sekolah, motivasi dan fasilitasi penerimaan siwa baru.

Jika dikaitkan dengan teori pertukaran, menurut Edgeworth (dalam Coleman, 2009 , p. 161), dalam pertukaran harus ada " ....persesuaian kebutuhan ganda (double coincidence of wants)..", yaitu keduanya membutuhkan barang yang dimiliki pihak lain, sehingga mereka bersedia menyerahkan apa yang dimiliki itu kepada pihak lain melalui pertukaran. Dari enam puluh organisasi lem- 
baga sosial kemasyarakatan yang ada di kota Salatiga, baru lima organisasi yang menjalin kerja sama kemitraan dengan sekolah SLTA kota Salatiga, yaitu PMI, MUI, KONI, Pramuka STAIN, dan Paguyuban Asmoro Budaya. Kelima lembaga sosial kemasyarakatan tersebut memiliki sesuatu yang dapat dipertukarkan dengan sekolah yang bersifat mutualistik.

Upaya sekolah menyampaikan informasi kepada masyarakat dan menginformasikan kegiatan masyarakat kepada peserta didik dan orang tua merupakan bentuk kesadaran akan arti penting informasi. Potensi informasi sebagai salah satu bentuk social capital sangat penting bagi individu atau kelompok individu. Sekolah adalah pihak yang dianggap valid dalam menyediakan informasi, baik informasi dari sekolah, masyarakat, orang tua maupun lainnya.

Sekolah sebagai bagian dari organisasi sosial berkepentingan untuk melakukan kegiatan integral dengan organisasi sosial lainnya guna menyelesaikan masalah, terutama berkaitan dengan human resources. Organisasi sosial menyediakan human resources yang melimpah yang dapat dimanfaatkan sekolah untuk menutup kekurangannya. Organisasi sosial juga menyediakan material capital, yang dapat dimanfaatkan sekolah untuk memperkaya kegiatan pembelajaran. Dalam hal ini yang terpenting adalah mempertemukan kesamaan gagasan, ide dan interest antara sekolah dan organisasi sosial yang ada.

\section{Pola Kemitraan Pendidikan}

Kemitraan pendidikan membentuk pola linier dalam proses pendidikan, yaitu linieritas proses kemitraan dari orientasi dasar pemikiran, jenis-jenis lembaga yang bermitra dan output yang dihasilkan. SMA yang memiliki dasar orientasi akademik-profesional, kekhasan kerja samanya dengan lembaga yang bergerak dalam bidang pengembangan akademik, dampak terhadap outputnya berupa lulusan yang memiliki kompetensi dalam bidang akademik tinggi; SMK yang memiliki dasar orientasi akademik-vokasional, kekhasan kerja samanya dengan lembaga-lembaga usaha atau DUDI, dampak terhadap outputnya berupa lulusan yang memiliki kompetensi vokasional memadai dan diterima kerja di berbagai perusahaan; sementara itu MAN yang memiliki dasar orientasi akademik-religius, kekhasan kerja samanya dengan lembaga keagamaan, dampak terhadap outputnya berupa lulusan yang memiliki kemampuan tahfidz dan perilaku perilaku religius misalnya tawadhu'.

Jika dikaitkan dengan bentuk modal sosial yang dikemukakan oleh Coleman (2009, p. 423), maka mitra-mitra kerja sama tersebut dapat dikategorikan ke dalam kewajiban dan ekspektasi, relasi wewenang, dan organisasi sosial. Dikatakan berbentuk kewajiban dan ekspektasi karena institusi-institusi tersebut merasa memiliki kewajiban yang sama untuk mendidik generasi muda agar menjadi generasi yang terampi sesuai dengan harapan.

Bentuk modal sosial relasi wewenang diwujudkan melalui kegiatan yang diselenggarakan oleh sekolah atau di masyarakat untuk membentuk suatu kompetensi tertentu. Kegiatan ini terlaksana karena pihak yang satu memiliki trust kepada pihak yang lainnya.

Modal sosial yang berbentuk organisasi sosial merupakan aktualisasi dari keinginan masyarakat untuk membantu komunitas sosial lain melalui organisasi-organisasi sosial. Organisasi sosial ini selain melaksanakan fungsi untuk memenuhi kebutuhan dirinya, juga memiliki misi sosial untuk membantu sesamanya yang memiliki kesamaan visi dan misi.

\section{Faktor Pendukung dan Penghambat}

Kemitraan antara sekolah, orang tua, dan lembaga sosial kemasyarakata di kota Salatiga dapat berjalan dengan baik didukung oleh berbagai faktor, baik dari sekolah, orang tua ataupun masyarakat. Faktor dari orang tua adalah munculnya kesadaran orang tua untuk datang ke sekolah dan proaktif berkonsultasi terkait dengan pendidikan anaknya di sekolah, Faktor dari siswa berupa munculnya kesadaran tinggi akan fungsi BK sebagai partner yang membantu mereka dalam meraih kesuksesan. Faktor dari sekolah berupa: (a) semangat profesionalisme para guru, karyawan dalam menjalankan tugas dan berinovasi; dan (b) petugas BK yang proaktif mengatasi masalah anak. Faktor dari elemen masyarakat berupa: (a) sikap koperatif berbagai elemen masyarakat untuk mendukung program kegiatan sekolah; dan (b) sikap kepedulian elemen masyarakat terhadap pendidikan anak di sekolah.

Menurut Petersen (2011, p. 21), untuk mengoptimalkan pengalaman dan partisipasi dalam kegiatan pendidikan, semua orang 
harus terlibat dalam kegiatan tersebut, baik sekolah, orang atau masyarakat. Petersen menyebutkan bahwa ..school, families and communities are blossoming together to support children's growth, knowledge, and development...some responsibilities are shared, and some are separate... a firm "root system" must support the entire relationship in order for a partnership to 'blossom' (sekolah, keluarga, dan masyarakat 'mekar' bersama mendorong pertumbuhan, pengetahuan, dan perkembangan anak....beberapa hal menjadi tanggung bersama...beberapa hal menjadi tanggung jawab masing-masing... sebuah usaha 'sistem akar' harus mendu-kung segala usaha kemitraan agar dapat 'mekar'). Dengan demikian, keberhasilan ke-mitraan akan terwujud manakal didukung oleh semua pihak, yaitu sekolah, keluarga dan masyarakat.

Orang tua merupakan salah satu sosial kapital bagi sekolah yang sangat berperan dalam pencapaian tujuan pendidikan di sekolah. Antar sekolah dan orang tua ada kewajiban dan ekspektasi yang mampu menggerakkan kedua elemen tersebut untuk melaksanakan tugas pendidikan. Sekolah memiliki kewajiban untuk melaksanakan tugas mendidik bagi anak-anak yang telah diserahkan orang tua kepada institusi tersebut, sementara orang tua memiliki ekspektasi yang terhadap sekolah atas keberhasilan anaknya dalam pendidikan di sekolah.

Beberapa faktor pengambat kemitraan pendidikan di kota Salatiga, muncul dari orang tua, siswa, dan sekolah. Faktor dari orang tua berupa: (a) sebagian orang tua tidak mau datang ke sekolah; (b) orang tua pasrah sepenuhnya kepada sekolah tentang urusan pendidikan anaknya; (c) perhatian orang tua terhadap pendidikan anaknya tergolong rendah; (d) status ekonomi orang tua tergolong lemah; (e) tingkat pendidikan orang tua rendah; (f) orang tua meremehkan sekolah. Faktor dari siswa adalah siswa tidak memberikan undangan dari sekolah kepada orang tuanya. Faktor dari sekolah adalah pihak sekolah lebih terkonsentrasi pada sukses UN, sekolah juga sedang berkonsentrasi dalam pembenahan manajemen internal.

Sementara itu, di sisi lain salah satu bentuk modal sosial lain adalah relasi wewenang, yaitu kewenangan yang diberikan oleh sesorang kepada orang lain sebagai relasinya untuk melakukan tindakan tertentu. Namun jika pemberian kewenangan berlebihan, sampai menimbulkan pasrah juga menimbulkan dampak yang kurang baik.

Sikap pasrah dalam pemberian wewenang ini cenderung terdapat pada keluarga dengan kondisi sosial, ekonomi, dan pendidikan rendah. Mereka merasa tidak mampu, kurang percaya diri (lack of efficacy, lack of confidence).

\section{Kemitraan Pendidikan pada Era Otonomi Daerah}

Dinas Pendidikan Pemuda dan olah raga (Disdikpora) kota Salatiga tidak mengeluarkan kebijakan khusus di era otonomi daerah terkait dengan pengembangan kemitraan pendidikan bagi satuan-satuan pendidikan. Disdikpora hanya menyarankan, mendorong kepada sekolah agar mengembangkan kerja sama dengan berbagai instansi terkait sesuai dengan jurusan masing-masing.

Dalam era otonomi daerah, yang berbeda adalah dalam pengambilan kebijakankebijakan pendidikan, dimana kebijakan diambil di tingkat kota. Namun hal ini justru itu sarat dengan 'permainan politik' sehingga menimbulkan banyak masalah dalam pelaksanaan pendidikan di era otonomi daerah ini.

Salah satu persoalan yang mengemuka di era otonomi daerah, yang juga dirasakan di kota Salatiga adalah munculnya rajaraja kecil di eksekutif, mereka tidak lagi mengabdi pada kepentingan rakyat secara luas, namun mereka lebih mengabdi pada kelompoknya dan pada kepentingan partai politik yang mengusungnya (Agustino, 2011, p. 106).

Kalau kita kaitkan dengan bahasan social capital, kepentingan politik yang mendominasi dalam pengambilan keputusan dan pelaksanaan kebijakan yang terjadi di Salatiga dapat merusak tatanan social capital. Menurut Coleman (2009, p.4 39), stabilitas politik termasuk salah satu aspek yang dapat merusak sosial capital. Dinamika politik yang mengedepankan pemenuhan kebutuhan individu dan golongan yang berkuasa, cenderung mengabaikan kepentingan orang banyak yang sebenarnya menjadi tanggung jawab mereka. Potensi capital yang ada di suatu daerah, tidak terdistribusikan kepada pihak-pihak yang semestinya memanfaatkannya, namun dibelokkan oleh para politisi dalam rangka pemenuhan kebutuhan mereka. 


\section{Dampak Kemitraan Pendidikan}

Kemitraan yang dikembangkan sekolah mengacu pada karakteristik khusus sekolah, yang berdampak pada performa lulusannya sesuai dengan karakteristik sekolah. SMA memiliki karakteristik dalam pengembangan kognitif dan menjalin kemitraan dengan berbagai instansi guna mendongkrak prestasi akademik peserta didiknya. Dampak terhadap lulusannya adalah tingginya perolehan nilai ujian akhir nasional dan diterimanya lulusannya di berbagai perguruan tinggi 'favorit'. SMK memiliki karakteristik dalam pengembangan keterampilan dan menjalin kemitraan dengan berbagai DUDI agar skill peserta didiknya meningkat, baik soft skill maupun hard skillnya. Dampak terhadap lulusannya adalah tingginya lulusan SMK yang diterima di berbagai DUDI. Sedangkan MAN memiliki kekhasan dalam bidang moral dan menjalin kemitraan dengan lembaga-lembaga yang dianggap mampu mensupport pembentukan moral peserta didiknya. Dampaknya terhadap lulusannya adalah mereka memiliki keunggulan dalam bidang keagamaan (misalnya hafal al Qur'an 30 juz) dan para lulusannya lebih dominan melanjutkan kuliah pada perguruan tinggi agama (misalnya ke IAIN).

Dampak kemitraan pendidikan terhadap orang tua adalah mereka lebih mengetahui akan tugas dan perannya dalam pendidikan anak, memahami bahwa di sekolah anak-anak dididik oleh para guru, memahami tentang program-program sekolah, keuangan sekolah dan anggaran belanja sekolah, di rumah, mereka harus senantiasa ikut mengawasi kegiatan anaknya. Menurut Epstein (2009, p. 18), kemitraan pendidikan sangat bermanfaat bagi orang tua peserta didik, komunikasi (communicating) membuat orang tua semakin memahami program dan kebijakan sekolah, menyadari akan perlunya memonitor kegiatan belajar anak, mampu merespond secara positif atas berbagai permasalahan anaknya, mampu berinteraksi dengan para guru atau pihak sekolah terkait dengan pendidikan anaknya.

\section{SIMPULAN DAN SARAN}

\section{Simpulan}

Sekolah memandang perlunya memanfaatkan berbagai sumber daya dalam masyarakat untuk mengatasi berbagai keter- batasan penyelenggaraan pendidikan dalam rangka memenuhi tuntutan kebutuhan masyarakat. Pengembangan kemitraan pendidikan di sekolah didukung oleh modal sosial yang dipengaruhi oleh jenis sekolah, inisiatif dan interest, keadaan orang tua, kebijakan sekolah dan partisipasi politik. Kemitraan pendidikan di sekolah mempengaruhi mutu sekolah, lulusan, dan orang tua.

\section{Saran}

Sekolah semestinya mengidentifikasi resources yang ada di sekitar sekolah dan dimenfaatkan untuk memperkaya pembelajaran. memperkaya pembelajaran. Sekolah perlu mendesain pengembangan kemitraan pendidikan secara sungguh-sungguh dalam rangka memperkuat eksistensi sekolah.

\section{DAFTAR PUSTAKA}

Agustino, L. (2011). Sisi gelap otonomi daerah. Bandung: Widya Padjajaran

Bahar, A. (1989). Dasar-dasar kependidikan. Depdikbud:PPL PTK

Berns, R.M .(2004). Child, family, school, and community. Colonia Polanco: Thomson Learning

Buchori, M .(2001). Pendidikan antisipatoris. Yogyakarta: Kanisius

Castiglione, D., Van Deth, J.W., \& Wolleb, G., (Ed). (2008). The Hanbook of social capital. New York: Oxford Univesity Press

Coleman, J.S .(2009). Dasar-dasar teori sosial. (Terjemahan Imam Muttaqien, Derta Sri Widowatie, SiwiPurwandari). Bandung: Nusa Media. (Buku asli diterbitkan tahun 1994).

Cox-Petersen, A .(2011). Educational partnership, connecting schools, families, and the community. California: Sage Publications, Inc

Creswell, J.W .(2007). Qualitative inquiry \& research design: Choosing among five approaches. California: Sage Publications, Inc. 
Decker, L.E \& Decker, V.A. (2003). Home, school, and community partnership. Oxford: Scarecrow Press, Inc

Depdiknas .(2002). Manajemen peningkatan mutu berbasis sekolah : Konsep dan pelaksanaan. Jakarta: Depdiknas Direktorat SLP

Epstein, J.L .(2009). School, family and community partnership. California: Crown Press

Glasser, W. (1990). The quality school: Managing students without coercion. New York:HarperCollins Publishers

Grant, K.B \& Ray, J.A .(2010). Home, school, and community collaboration. California: SAGE Publications, Inc

Hauberer, J. (2011). Social capital theory: Toward methodological foundation. Heidelberg: Springer Fachmedien

Hopkins, D. (2007). Every school a great school: Realizing the potential of system leadership. Maidenhead:Open University Press

Idi, A. (2013). Sosiologi pendidikan: Individu, Masyarakat, dan Pendidikan. Jakarta: RajaGrafindo.

Jalal, F \& Supriyadi, D (Ed). (2001). Reformasi pendidikan dalam konteks otonomi daerah. Adicita:Yogyakarta

Jensen, E., (2010). Guru Super \& Super Guru. (Terjemahan Benyamin Molan). Jakarta Barat:Indeks

Maliki, Z. (2010). Sosiologi pendidikan. Yogyakarta: Gadjah Mada University Press

Marsh, C. (2010). Becoming a teacher: Knowledge, skills, and issues. French Fores:Pearson

McDermott, D .(2008). Developing caring relationships among parents, children, schools, and communities. California: Sage Publications, Inc
Nasution .(2005). Manajemen mutu terpadu. Bogor:Ghalia Indonesia

Novi, S.R. (2012). Sarapan nasi agar otak lebih cerdas. Diambil pada tanggal 9 Februari 2015 dari Error! Hyperlink reference not valid. .

Olsen\&Fuller, M.O. (2012). Home and school relation. New Jersey:Pearson

Paretta, L. (2004). Makanan untuk Otak (Terjemahan Shinta Teviningrum). Jakarta: Erlangga

Robins, S.P., \&Judge, T.A.,. (2007). Perilaku organisasi, Buku 1 edisi 12. (Terjemahan Diana Angelica). Jakarta:Salemba Empat

Schunk, D.H., Pintrich, P.R., \& Meece, J.L,. (2012). Motivasi dalam pendidikan:Teori, penelitian dan aplikasi. (Terjemahan Ellys Tjo). Kembangan Utara:Indeks

Tate, M.L. (2013.) Menyiapkan anak untuk sukses di sekolah dan kehidupan : 20 cara untuk meningkatkan kekuatan otak anak anda. (Terjemahan Dyah Widya Prabaningrum). Kembangan Utara:Indeks

Unoviana. (2014). Lima makanan yang menurunkan kinerja otak, Kompas 19-04-2014. Diambil pada tanggal 6 Oktober 2014 dari Error! Hyperlink reference not valid.

Weiss.,et.al. (2010). Preparing educator to engage families. City Road:SAGE Publication, Inc.

Widjaya, A. (2014). Tujuh Makanan yang bikin ngantuk. Diambil pada tanggal 16 Januari 2015 dari http://andywidjayaa.blogspot.co.id/20 14/11/7-makanan-yang-bikinngantuk.html.

Yukl, G., (1998). Kepemimpinan dalam organisasi. (Terjemahan Jusuf Udaya). Jakarta: Prehallindo. 